\title{
Turizm ve Rekreasyon Araştırmalarında Çoklu Oylama, Pareto Analizi ve Balık Kılçı̆̆ı Tekniklerinin Kullanımı
}

\author{
Özkan TÜTÜNCÜ*, Betül KORKMAZ ORHAN**, Seda ÖZDEMIR AKGÜL *** \\ *Prof. Dr., Dokuz Eylül Üniversitesi, Necat Hepkon Spor Bilimleri Fakültesi, \\ **Araş. Gör., Selçuk Üniversitesi, Turizm Fakültesi \\ ***Araş. Gör. Dr., Selçuk Üniversitesi, Turizm Fakültesi,
}

\section{Giriş}

Turizm ve rekreasyon alanında yapilan bilimsel çalışmalar temel olarak nitel, nicel veya karma araştırma yöntemlerinden yararlanmaktadır. Alanda çalışan araştırmacılar, genel olarak bilimsel yöntem ile ilgili temel bilgilere sahip oldukları için yapılan çalışmaları okuduklarında, bilimsel bazı sonuçlara ulaşabilmektedir. Öte yandan tüm ülkelerde olduğu gibi ülkemizde de turizm veya boş zaman endüstrisinde çalışan alanın uygulayıcıları bu araştırmaları okuduklarında, onlar için bu çalışmalar pek bir şey ifade etmeyebilir. Buradaki temel sorun, hepimizin genel olarak bildiği mektepli ve alaylı yaklaşımı ile ilintili olmakla birlikte, işin gözden kaçan başka noktaları da bulunmaktadır.

Evvelden alaylı olarak ele alınan belli bir tedrisattan geçmemiş veya lisans eğitimini tamamlamamış yöneticiler çokken, şu an alanda çalışan lisans eğitimini tamamlamamış bir yönetici bulmak zordur. Hatta özellikle turizm sektörüne bakıldığında birçok beş yıldızlı otelde, turizm ve otelcilik yüksekokulu (şu an birçoğu fakülte olan) mezunlarını görmek mümkündür. Bununla birlikte mektepli olan ve uzun yıllardır sektörde çalışan sektör yöneticileri, turizm ve rekreasyon alanında çalışan bilim insanlarının yaptıkları araştırmaların kendilerine çok büyük katkılar yapmadığını belirtmektedir.

Bilim insanlarının yapacakları araştırma projelerine destek için herhangi bir üst kuruma başvurularında aranan kriterlerden biri, özel sektör, kamu ve demokratik kitle örgütleri (bugünlerde sivil toplum kuruluşu olarak adlandırılan!) iş birliğinin olmasıdır. Diğer bir ifade ile araştırmacıların sektörden ve halktan kopmadan, toplumun anlayacağı ve tüm paydaşlara katkı sağlayabilecek çalışmalar yapmasının teşvik edilmesi amaçlanmaktadır. Yüksek rekabetin olduğu sektörümüzde çalışan yöneticiler, çoğu zaman yapılan araştırmaların çok teorik olmasından yakınmakta ve bu araştırmaların kendilerine pratik katkı sağlamadığından dem vurmaktadır. İşin aslı teorik bilgiye sahip olan araştırmacılar dahi, bazen bu araştırmaların içinde ne teorik ne de pratik bir katkı gördüklerini beyan etmektedir. Bununla birlikte sektörün eğitimli çalışanları, bu çalışmaların kendileri açısından birtakım eksiklikleri olduğunu nazikçe belirtmektedir.

Anatolia Turizm Akademisi, bu eksiklikleri görmüş olmalı ki Türkiye'de belki de dünyaya örnek olacak, sektör-akademi ortak çalışmasına öncülük eden arama konferanslarını 23 Nisan 2009'da başlatmıştır. Buradaki temel amaç, özellikle turizm akademik eğitimi ve araştırmalarında, ortak aklı kullanabilmek olmuştur. 2019 yılına kadar (KOVID-19 salgını öncesi) hız kesmeden 11 yılda 15 arama konferansı düzenlenmiştir. Daha da ilginci, geliştirilen arama konferansı yöntemi, alanda çalışan diğer bilim insanlarının dikkatini çekmiş ve sektörle ortaklaşa yapılan projelerde değerlendirilen önemli nitel yöntemlerden biri olmuştur. Derginin rekreasyon incelemeleri köşe yazarı da hasbelkader bu çalışmaların bir kısmında yer alma fırsatı bulmuştur. Burada yapılan 
arama konferanslarından yola çıkılarak, sektörakademi iş birliğinin daha sağlıklı ilerleyebilmesi, yapılan turizm ve rekreasyon araştırmalarının sonuçlarının daha iyi anlaşılabilmesi ve pratik katkılar sağlayabilmesi için nitel araştırmalarda kullanılabilecek bazı tekniklere değinilecektir.

\section{ARAMA KONFERANSLARININ TEMEL ÖZELLIKLERi}

Arama konferansları önceden beyin fırtınası ile belirlenen o dönem için öncelikli bir sorunun çözümü amacıyla yapılmaktadır. Bu çalışma "Konya Turizmi Gelecek Vizyonu Ortak Akıl Arama Konferansı" kapsamında ele alınmaktadır. Bu nedenle, burada ele alınacak aracı nitel teknikler, belirtilen konferans üzerinden örneklendirilerek değerlendirilecektir. KOVID-19 salgınından dolayı konferans uzaktan bağlantı yöntemiyle yapılmış ve tüm katılımcılar, bir internet platformu üzerinden gönüllü olarak çalışmada yer almıştır. İlginç olan, uzaktan bağlantı ile aktif ve başarılı bir arama konferansı gerçekleştirilmiş olmasıdır. Bununla birlikte arama konferanslarının özellikle uzaktan bağlantı yöntemiyle yapılmasında, başarılarını etkileyen iki dışsal unsurun bulunduğu belirtilmelidir. Bunlardan biri çok iyi bir internet ve yazılım desteği, diğeri ise katılımcıların tüm oturumlara katılma hassasiyeti ve teknolojiye yatkınlıklarıdır. Katılımcıların gelecekten etkilenen ve geleceği etkileyen, gelecek ile ilgili problemlerin çözülmesindeki alternatiflerden çıkarı olan kimseler olmasına dikkat edilmektedir. Katılımcıların temel özellikleri şu şekilde ele alınabilir:

- Karar vericilerin, uygulayıcıların, ilgili ve yetkili yöneticilerin katılmasına özen gösterilir.

- Katılımciların yapisı heterojendir.

- Toplantı süresince rütbe, statü, yetki, yaş veya bir meslek grubuna ait olmak katılımcıların varsayımlarını etkilese de oturumlarda bir öncelik veya bir ayrıcalık sağlamaz.

- Gönüllü katılım önemlidir.

- Katılımcılardan kendi fikirleri kadar, diğer fikirleri dinlemeye önem vermeleri, yeni veya alışılagelmiş fikirlere önyargılı yaklaşmamaları, kavgacı değil uzlaşmacı olmaları beklenir.
- Arama konferansı, klasik bir konferans türü değildir. Uzun konuşmalar yapılmaz (en fazla üç dakika). Katılımcı sayısı fazla, konuşma süresi kısıtlı olan bir tür odak grup çalışmasıdır.

$\mathrm{Bu}$ ana belirlemelerin ardindan arama konferansina davet edilen, sektörün ve akademik camia temsilcilerinin belirtilen tarih aralığında tüm çalışmalarda yer almaları gerektiği teyidi ile konferans başlamıştır. Arama konferanslarında uyulması gereken bazı kurallar bulunmaktadır. Bunlar, şu şekilde sıralanabilir:

- Katılımcilar, tüm toplantılara katılırlar. Konferans ve çalıştay (atölye çalışması) sürecinin evreleri birbiri ile ilişkili olduğu için bir bölümüne katılıp, diğer bölümüne katılmama durumu yoktur. Bu nedenle, konferans başlangıcında tüm katılımciların teyidi alınır.

- Katılımcılar konferans ve çalıştaylar bitinceye kadar hiçbir şekilde rahatsız edilmemeli ve çalışma ortamından ayrılmamalıdır.

- Çalışmanın başlangıcında kısa bir ısınma egzersizi (buz kırma etkinliği) uygulanabilir.

- Her grup kendi içinde sorunlara yönelik serbest beyin fırtınası yöntemi uygulayabilir. Moderatör, çalıştay grup başkanlarına sadece yöntem konusunda yardımcı olur.

- Her bir grup üyesinden veri almaya çalışılır. Veri alınamayan grup üyeleri, çalışmaya katılımlarının sağlanması için motive edilir.

- Grup üyelerine olumsuz yaklaşım sergilenmez ve tenkitlerden kaçınılır.

Konferans, kısa bir tanışma ve buz kırma etkinliği ile başlamaktadır. Daha sonra belirlenen sorun çerçevesinde GZFT (SWOT) analizi yapılmaktadır. GZFT bir projenin güçlü $(G)$ yanlarını, zayıf $(\mathrm{Z})$ yönlerini, fırsatlarını $(\mathrm{F})$ ve tehditlerini $(\mathrm{T})$ listeleyerek ve düzenleyerek, projeye yardım edebilecek veya zarar verebilecek unsurları, açık ve kolay anlaşılabilir bir yol haritası planlamak ve organize etmek amaciyla yapılmaktadır. Arama konferansının pratik katkısı kontrol edilebilen içsel faktörlere daha fazla dayandığından, katılımcıların ve ardından oluşturulan grupların öncelikle güçlü ve zayıf yönlere odaklanması, tehdit ve fırsatları kontrol edebilme durumuna göre bu 
kapsamda değerlendirmeleri daha faydalı olabilmektedir. GZFT analizine bağlı olarak, katılımcıların özellikle listelenmiş tüm zayıf yönler ve tehditlerden hareketle, araştırma projesinin ana kollarını nelerin oluşturduğunu tespit etmeleri istenmektedir. Ortak görüşe varıldıktan sonra belirlenen ana sorunlar çerçevesinde çalışma grupları oluşturularak, çalıştaylar yapılmakta ve grupların sorunlara güçlü yönlerden ve fırsatlardan hareketle çözüm önerileri getirmeleri istenmektedir. Ardından grup liderleri kendi çalışma alanları ile ilgili yaklaşık on beş dakikalık bir sunum yapmakta, gelen eleştiriler ve öneriler doğrultusunda tüm katılımcıların hemfikir olmasıyla, her grup kendi çalışma özetini sunmaktadır. Daha sonra tüm grupların önerileri bir araya getirilerek, ana sonuç raporu oluşturulmaktadır.

\section{YÖNTEM}

Bu yazıyı kaleme alan üç yazar, 13-17 Temmuz 2020 tarihinde katılımcı gözlemci olarak “Konya Turizmi Gelecek Vizyonu Ortak Akıl Arama Konferansı"nda yer almıştır. Katılımcı gözlem, araştırmacının bilgi verenlerin söylemleri ve eylemleri arasındaki tutarlılığı doğrulamasını sağlayan güvenilirliği yüksek bir metodolojidir (Meneses-Falcón 2020). Doğrudan gözlemden ziyade sözlü anlatımlara ve davranışlara odaklanan katılımcı gözlem, nadiren kullanılan bir nitel araştırma yöntemi olarak değerlendirilebilir. Diğer nitel araştırma yöntemlerine göre en önemli avantajı, araştırmacıların konuyla alakalı olan ama gözden kaçan veya ihmal edilen nadir verileri de rapor etmesine olanak sağlamasıdır (Power 2001). Katılımcı gözlemi diğer nitel araştırma yöntemlerinden ayıran özelliği, araştırmanın önemli bir parçası olan araştırmacının duyusal, duygusal ve somut deneyimini araştırmaya yansitabilmesidir (Walsh 2020). Aktinson ve Hammersley (1998), toplumun bir parçası olmadan sosyal araştırmaların yapılamayacağı dolayısıyla tüm araştırmacıların aynı zamanda birer katılımc1 gözlemci olduğu düşüncesine istinaden, katılımcı gözlemin bir araştırma tekniği olmaktan öte sosyal hayatın içinde var olma şekli olduğunu savunmaktadır.
Bu çalışmada katılımcı gözlemci olarak yer alan yazarların, sadece konferansın yöntemi üzerine odaklandıkları vurgulanmalı ve bu yönüyle klasik olarak tüm süreci bütünlemesine analiz eden bir gözlemden ziyade, sadece spesifik bir boyuta odaklandıkları göz ardı edilmemelidir. Ayrıca katılımcı gözlemci olarak yapılan çalışmalar, genel olarak tek bir araştırmacının yaptığı gözlemlere dayanmaktadır. Bu çalışmada üç araştırma$\mathrm{Cl}$, sürecin içinde yer almıştır. Sürecin bitiminde üç araştırmacının ortak görüşleri doğrultusunda, bu tür araştırmalarda kullanılabilecek aracı nitel teknikler, uygulamalı bir örnek ile değerlendirilmiştir.

\section{ARAŞTIRMALARDA KULLANABILECEK ARACI NITEL TEKNIKLER}

Arama konferanslarının yöntemsel ilerlemesi, belirlenen bir sorun çerçevesinde alanın uzmanı katılımcıların önce GZFT ile ana sorun alanları$\mathrm{n}$ belirlemesine ve ardından çalıştaylar ile bu sorunlara çözüm aramasına odaklanmaktadır. Nitel araştırma yöntemlerinde kullanılan içerik analizine kısmen benzemektedir. Öncelikle katılımcıların sorun ile ilgili tüm görüşleri alınmaktadır. Ardından aslında içerik analizinde yer alan temalandırma aşamasına, ifade edilmiş olan tüm sorunlardan yola çıkılarak, doğrudan geçilmektedir. Bunun temel amacı, çalışma gruplarının oluşturulup, bu temalar üzerinden var olan sorunlara çözüm üretmelerinin sağlanmasıdır. Oysaki bir içerik analizinde süreç, önce elde edilen bilgilerin kodlanmasına, ardından kodlardan hareketle kategorilerin oluşturulmasına ve en sonunda ise temaların oluşturulmasına odaklanılarak yürütülmektedir.

GZFT'den elde edilen görüşlerden sonra, ana çalışma konuları moderatör tarafından, katılımc1ların görüşleri dahilinde genel bir belirleme ile yapılmaktadır. Diğer bir ifade ile temalandırma çok hızlı bir şekilde yürütülmekte ki bu, sınırlı zamanın odak gruplardaki gibi aktif kullanılması zorunluluğundan kaynaklanmaktadır. Çalışma daha sonra katılımcıların inisiyatifiyle belirlenen temalar çerçevesinde, GZFT'deki zayıf yönlerin güçlü yönler yardımıyla, tehditlerin ise 
fırsatlar yardımıyla çözümüne odaklanmaktadır. GZFT'de gözden kaçan noktaların ise çalıştaylarda katılımciların önerileriyle giderilmesi sağlanmaktadır. Bu aşamaların klasik içerik analizinden en büyük farkı, temanın ilk başta hızlı bir şekilde belirlenmesinden ve daha sonra kodlama ve kategorilerin tam yapılmamasından kaynaklanmaktadır.

Arama konferansında ve çalışmada yer alan araştırmacılar, bu sürecin içerik analizine uygun olarak yürütülmesine ve daha sağlıklı öneriler getirilebilmesine yönelik olarak, kalite yönetiminde kullanılan kalite geliştirme tekniklerinden bazılarının, buraya uyarlanabileceğini öngörmektedir. Bu kapsamda kalite üstatları Juran, Deming ve Ishikawa'nın İkinci Dünya Savaşı sonrası Japonya'da başlattıkları kalite hamlesinde kullanılan ve pratik katkı sağlayan kalite geliştirme araçlarına odaklanılmaktadır. Bilindiği üzere kalite, Türkçemizde nitelik anlamına gelmektedir. Bu açıdan tamamıyla kalite geliştirme araçları, özellikle nitel araştırmalar için yardımcı araçlar olarak kullanılabilir. Bununla birlikte Japonya'da özellikle kuramın uygulamaya (pratiğe) dönmesinde hem nitel hem de nicel araştırmalarda değerlendirildikleri, göz ardı edilmemelidir.

Arama konferanslarında temalar, çalışma gruplarının oluşturulabilmesi için sürecin tüm aşamaları tam olarak ilerlemeden veya olgunlaşmadan hızla belirlenmelidir. Bu aşamanın daha doğru yürütülebilmesi için çoklu oylama ve pareto destekli bir kategorizasyon süreci yürütülebilir. Diğer bir ifade ile en azından katılımcıların kendi içlerinde bir kodlama yapıp, ardından bunları kategorilere indirgemeleri sağlanabilir. Bu kısmın en son aşamasında, yine ortak akıl ile çalışma gruplarının üzerinde duracağ ${ }_{1}$ ana çalışma sorunları veya temaları saptanabilecektir. Ancak bu, sadece çalışma gruplarının sorun alanları için bir ön tema belirlemesi olarak ele alınmalıdır. Ardından çalışma grupları, kendi sorun alanlarına yönelik GZFT'den elde edilen bilgileri kodlamalı, kategorileri oluşturmalı ve nihai temalarına ulaşmalıdır. İşte bu son aşamada Ishikawa'nın balık kılçı ̆̆ rarlanılarak, içerik analizi görsel bir şekilde tamamlanabilir. Bu süreçler, burada uygulamalı bir örnek üzerinden ele alınmaya çalışılacaktir

\section{Çoklu Oylama (Multivoting)}

Çoklu oylama, katılımcıların her yanıt için eşit sayıda oy hakkının bulunduğu, verilen yanıtların oy çokluğuna göre sıralandığı ve azalan yanıtlar arasında seçimlerin yapıldığı bir karar verme tekniğidir (Nothnagle vd. 2008). Özetle çoklu oylama, katılımcılar tarafından beyin fırtınası yöntemiyle oluşturulan listedeki her bir madde için önemli ögeler belirlenene kadar oylama yapmaya dayanan bir karar verme tekniğidir. Yapılan en az iki turlu veya çok turlu bir seçimdir.

Arama konferanslarında GZFT yapıldıktan sonra özellikle zayıf yönlere odaklanılarak, bu aşamaya geçilebilir. Konya turizminin geleceğe yönelik vizyonunu belirlemek amacıyla yapılana arama konferansında 71 adet zayıf, 53 adet güçlü yön bulunmuştur. Çoklu oylamanın ilk turunda Konya turizmini olumsuz etkileyen 71 sorun içinden, katılımcıların ilk turda kendileri için en önemli olduğunu düşündükleri üç ana sorunu belirlemeleri istenmiştir. Tüm katılımcıların belirlediği zayıf maddelerin bir çetelesi tutulmuştur. Oy çokluğuna göre sıralanan yanıtlar içerisinde birbirine benzerlik gösterenler birleştirilerek, numaralandırılmakta ve oylama işlemi tekrarlanmaktadır. İlk turda ikinin üzerinde oy alan tüm zayıf alanlar, çoklu oylama kapsamında ikinci tur seçimine alınmıştır. İkinci turda katılımcılardan en önemli iki sorunu seçmeleri talep edilmiştir. Böylelikle ilk turda kendileri için önemli olduğunu düşünen ve elenen maddeleri seçen katılımc1ların, ikinci turda sürece katılmaları sağlanmış ve tüm katılımcıların önerileri dahilinde en önemli sorunlar ortaya çıkarılmıştır. Tur sayısını Pareto kuralı belirlemektedir. Konya'daki arama konferansinda ikinci tur sonucunda yeterli ana temaları belirleyecek kategorilerin oluşması sağlanmıştir.

\section{Pareto Analizi}

Pareto analizinin temelleri, ekonomi uzmanı Vilfredo Pareto (1897) tarafından ülkelerdeki gelir dağılımının eşitsizliğine dikkat çekmek amacıyla oluşturulmuştur. Aslında Pareto'nun özetlemek 
istediği, milli gelirin büyük çoğunluğu olan \% 80 'in toplumun küçük bir azınlığı olan zengin \% 20'lik grup tarafından, gelirin geri kalan az kısmı olan \% 20'nin, toplumun çoğunluğu olan \% 80'lik fakir halk tarafından elde edilip, kullanıldığıdır. Juran (1975), bu kuralı endüstrilerdeki sorunlarla ilgili olarak kullanılabileceğini vurgulamış ve sorunların \%80'nin sistemden, \% 20'sinin bireylerden kaynaklandığını saptamıştır. Juran'a (1954) göre bu analiz bir iyileştirme, planlama ve kontrol sürecinin başarılı olması için hayati önem taşıyan azınlığın belirlenmesi analizi olarak ele alınmaktadır. Eğer ilgili endüstrideki önemli ilk \% 20'lik sorun belirlenir ve sadece bunlar çözümlenirse, o endüstri ile ilgili olarak en az \% 80'lik katkı ve gelişim sağlanabilmektedir (Radson ve Boyd 1997). Bu kapsamda var olan en önemli birkaç problemin, toplam problem üzerinde önemli etkisi olduğundan hareketle ana sorunların bir sistematik dahilinde belirlenmesi gerekmektedir. Pareto analizi, çoklu oylama sistemi ile desteklenebilmektedir. Pareto analizinin kısa vadeli veya geçici sorunlar yerine (teknik arıza, mevsimsel dalgalanmalar, vb.), süreklilik gösteren ve rutin sorunların çözümünde kullanılmasının daha gerçekçi olduğu savunulmaktadır (Knights 2001).

Arama konferansinda yapılan ikinci turun ardından saptanan \% 20'de yer alan sorunlar, kategorilerin oluşmasına yardımcı olmuştur. Ardından ana sorunların (temaların) hangi gruplar altında toplanabileceği bir beyin fırtınası çalışması ile belirlenmiş ve Konya turizminin gelecek vizyonuna katkıda bulunabilmek amacıyla gastronomi ve mutfak sanatları, marka ve imaj, tanitım ve pazarlama, alt ve üst yapı ile turistik ürün çeşitlendirme başlıkları altında çalışma grupları oluşturulmuştur. Böylelikle çalışma gruplarının esas sorun alanları belirlenmiştir. Ancak buradaki temaların tekrar iyi bir şekilde analiz edilmesi, çalıştaylarda çalışan katılımcıların becerilerine dayanmaktadır. Bu noktada diğer bir kalite geliştirme aracı olan balık kılçığı şemalarından yararlanılabilir.

\section{Balık Kılçığı Şeması}

Kalite geliştirme tekniklerinden biri olan balık kılçığı diyagramı, "neden-sonuç analizi" veya
"Ishikawa diyagramı" olarak da adlandırılmaktadır. Balık kılçı̆̆ı şeması, ana nedenler ve alt nedenler arasındaki ilişkilerin görsel olarak sıralanarak (Bhattacharjee vd. 2014) birden fazla nedeni olan olayların risklerinin belirlenmesine olanak sağlayan, uygulanması kolay olan grafiksel bir analiz aracıdır (Ilie ve Ciocoiu 2010). Şemanın şekli bir balığın kılçıklarına benzediği için bu şekilde adlandırılmaktadır. Balık kılçı̆̆ı şeması sorunun tanımlanması, ana nedenlerin belirlenmesi, olası nedenlerin belirlenmesi ve diyagramın analiz edilmesi olmak üzere dört aşamadan oluşmaktadır (Liliana 2016). Şemanın baş kısmına "sorun", büyük kılçı dallarına "ana faktörler", ara kılçık kısımlarına ise "alt faktörler" sıralanmaktadır. Sorunlar ve buna neden olan faktörler arasındaki ilişkileri sistematik bir şekilde görselleştiren analiz biçimidir. Bu şemalar birkaç neden arasında, hangisinin en büyük etkiye sahip olduğunu belirlemeye yardımcı olmaktadır (Varzakas 2016).

Balık kılçığı şemalarında izlenilen süreç, öncelikle ana sorunun belirlenmesi ardından ana kılçık kollarının saptanması ve ardından alt sorunlara değinilmesi üzerinedir. Diğer bir ifade ile içerik analizinin tersi olarak gerçekleşmektedir. Öte yandan arama konferanslarının yapısı, içerik analizinin normal sürecinin balık kılçık şemalarında uygulanmasına olanak vermektedir. Çalışma ana sorunları belirlenen atölye grupları kendi içlerinde beyin fırtınası yaparak, GZFT'de dile getirilmiş sorunları kodlayabilmektedir. Ardından bu kodlamalara bağlı olarak çalışılabilecek kategoriler oluşturulabilmektedir. Bu kategoriler, çalışılacak ana temaları ortaya çıkarmaktadır. Bununla birlikte özellikle pratik zekaya sahip katılımcılar, ana temaların belirlenen sorun kümelerinden yola çıkarak, neler olabileceğini öngörmektedir.

\section{Balık Kılçığı Şemasının Uygulanması}

Konya turizmine yönelik yapılan GZFT analizi sonucu, ortaya konulan verilerden hareketle gerçekleştirilen çoklu oylama destekli ana sorunlardan (temalardan) birini turistik ürün çeşitliliği oluşturmaktadır. Bu konuyla ilgili çalışmak isteyen gönüllülerden oluşan grup, ilgili sorunu 
tam belirlemek ve çözüm önerileri bulmak amacıyla çalıştayına başlamıştır. İlgili grup yaptığı çalıştayda ana sorunu "turistik ürün çeşitlemesinin yetersizliği" olarak tespit etmiştir. Buna bağlı olarak yaşanan diğer sorunları; turistik ürün çeşitlenmesinin yetersizliği ile ilgili belirsizliğin oluşması, turistik ürüne dönüştürülemeyen değerler/turistik ürünler, Konya'daki turistik ürün çeşitlenmesinden paydaşların pay alamaması, turistik ürün çeşitlenmesine yönelik festival ve diğer organizasyonların yapısal sorunlarının olması, turistik ürün çeşitlenmesi ile ilgili alınan kararların uygulamaya konulmaması ve inanç turizmi ile ilgili ürün çeşitliliğinin yapılamaması olarak belirlemiştir.

Belirtilen sorunlara yönelik çalışan katılımcılar, grup liderlerini belirleyerek alanlarına özgü sorunlarını ve çözüm önerilerini tüm katılımcıla- ra on beş dakikalık bir oturumda sunmuşlardır. Arama konferanslarinda sunulan tablolar; sorunun tanımı, çözüm önerileri, ilgili kurum ve kuruluşlar, izlenecek yöntem ve süreyi kapsamaktadır. Sunumun akabinde diğer grupların katılımcılarından gelen eleştiri ve öneriler değerlendirilmiştir. Herkesin hemfikir olmasına bağlı olarak, ilgili grup tablolarını güncelleyerek, nihai raporunu oluşturmuştur. Konferansta katılımcı gözlemci olarak yer alan çalışmanın yazarları ise bu tablolardan hareketle iki balık kılçığı şeması hazırlayarak, yapılan çalışmaları aşağıda özetlemeye çalışmışlardır.

\section{SONUÇ}

Arama konferansları özellikle sektör ve akademisyenleri diğer bir ifade ile alan uzmanlarını bir araya getiren ve belirlenmiş sorunlara yöne-

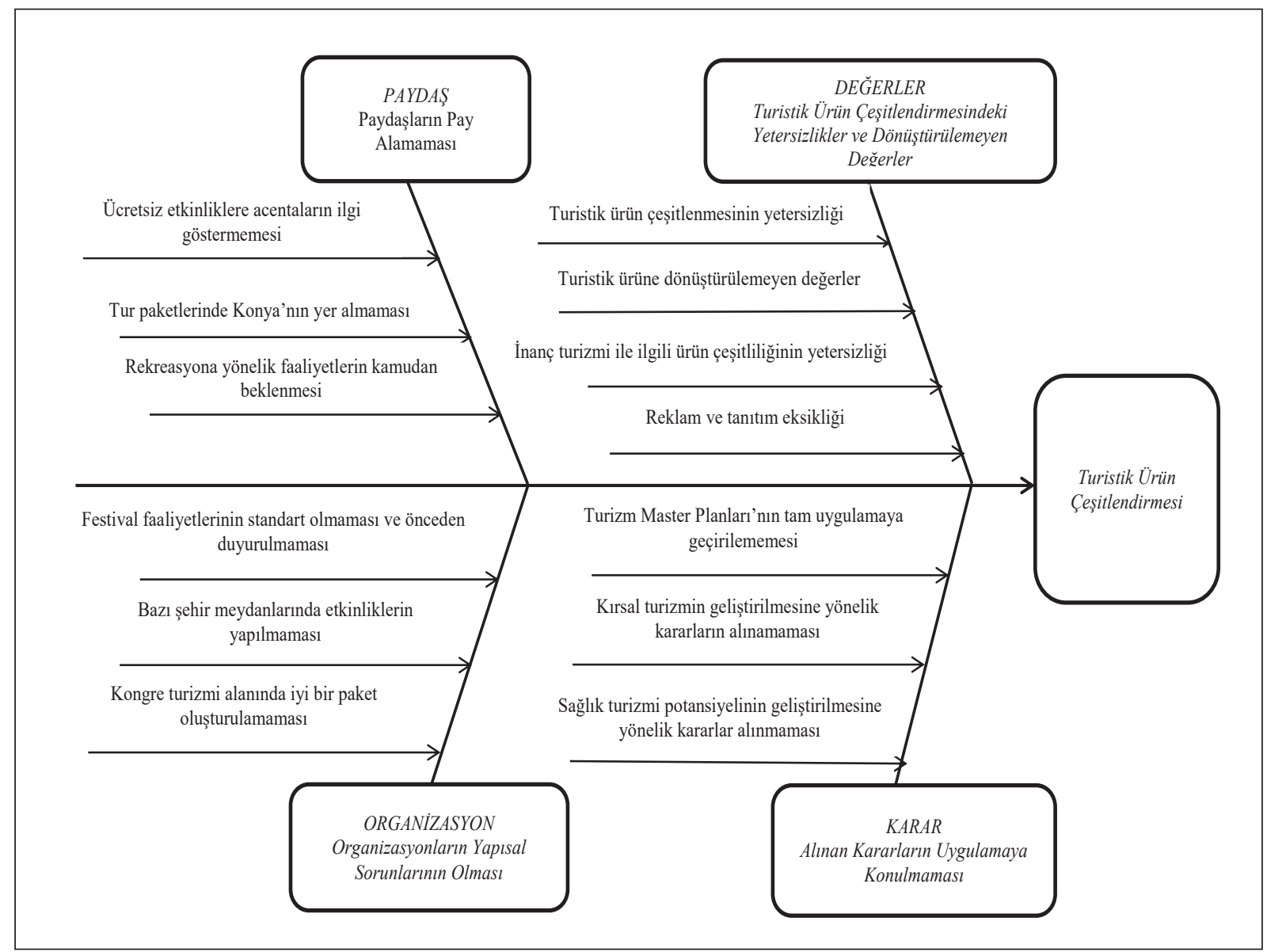

Şekil 1. Turistik Ürün Çeşitlendirmesine İlişkin Balık Kılçı̆̆ı Şeması 


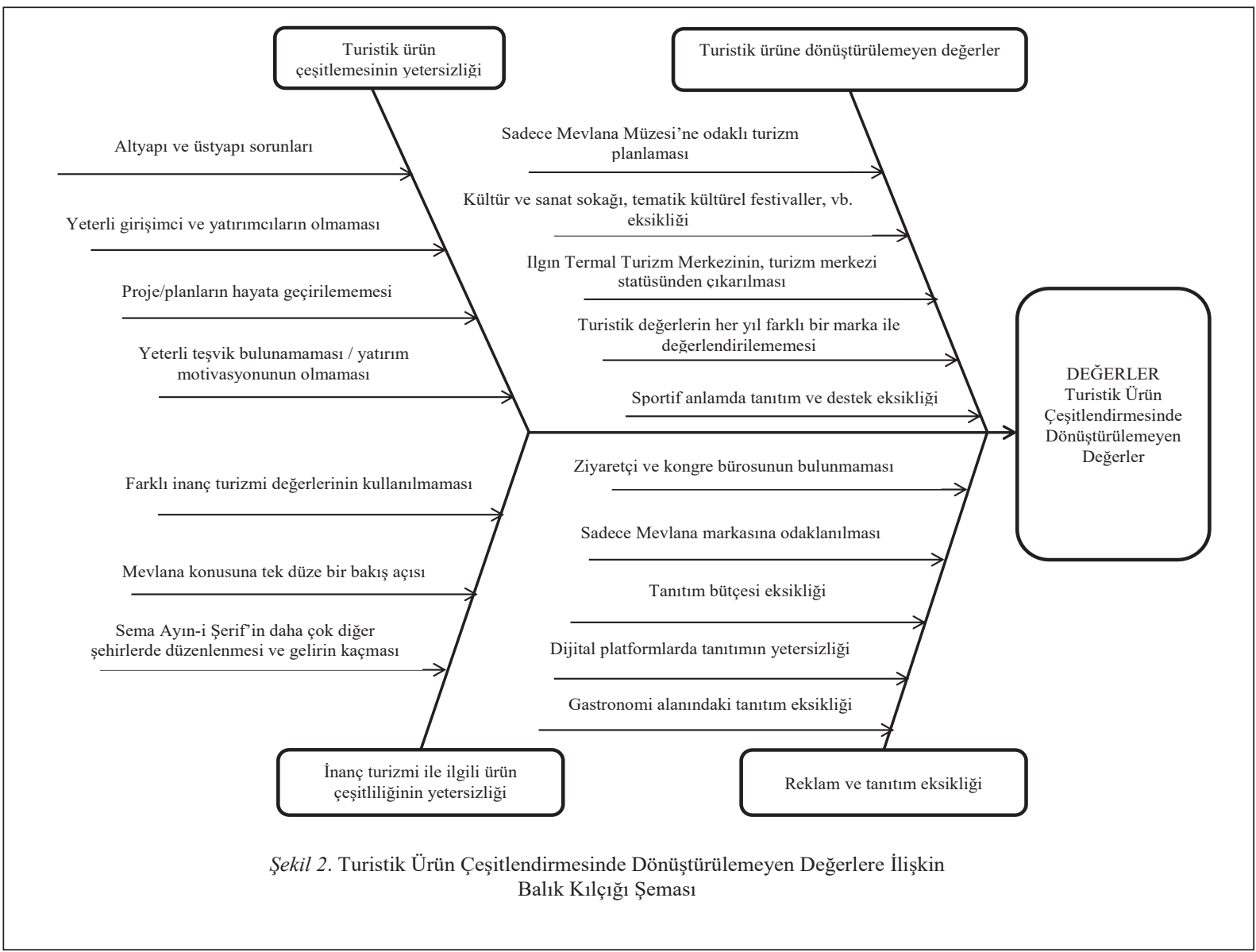

Şekil 2. Turistik Ürün Çeşitlendirmesinde Dönüştürülemeyen Değerlere İlişkin Balık K1lçı̆̆ı Şeması

lik beyin fırtınası ile atölye çalışmalarında çözüm üreten etkinliklerdir. Sorunların çözümüne yönelik ister arama konferanslarıyla ister başka yöntemlerle çözüm aransın, bu tür etkinliklerde pratik katkı sağlayabilmek amacıyla farklı bilimsel çalışma alanlarında kullanılan tekniklerden yararlanmak, çok disiplinli ve disiplinler araS1 çalışmayı zorunlu kılan turizm ve rekreasyon alanının doğasıyla, doğrudan örtüşmektedir. Japonya'nın kalkınmasında büyük yer tutan kalite hareketinin araçları olan çoklu oylama, pareto analizi ve neden-sonuç şemaları, alanımızda kullanılabilecek önemli tekniklerdir.

Arama konferanslarında belirlenen sorunlara bağlı olarak oluşturulan grupların yaptıkları çalıştayı raporlarken kullandıkları tablolara ek olarak, Ishikawa balık kılçı̆̆ı şemalarını kullanmaları, sorunların daha iyi anlaşılmasına katkı sağ- lamaktadır. Buna yardımcı olmasının en önemli nedenlerinden biri, içerik analizinin unsurlarını içinde bulundurması olabilir. Diğer bir ifade ile pareto ve çoklu oylama ön çalışması ile belirlenen ilk aşamadaki temalar, gruplar tarafından GZFT analizine bağlı olarak bir nevi içerik analizine tabi tutulmaktadır. İlk aşamada kodlamalar yapılmakta, ardından kategoriler oluşturulmakta ve nihayetinde ana temalar belirlenmektedir. Verilen örneklerde olduğu gibi balık kılçığının başı temayı, ana kılçık kolları kategorileri, her bir kılçık dalı ise kodlamaları göstermektedir. İnsanların şekilleri nesir yazılardan daha iyi algılamaları, yapılan bir çeşit içerik analizinin de kısa ve anlamlı özetini oluşturmaktadır.

Ele alınan soruna bağlı olarak balık kılçı̆̆ında oluşan her bir ana kılçık kolu veya kategorisi, daha sonra istenilirse bir başka balık kılçığı ile ay- 
rı bir tema olarak daha detaylı analiz edilebilir. Yukarıda Şekil 1'de ilk aşamada ele alınan değerler kategorisi, bir sonraki balık kılçı̆̆ının (Şekil 2) ana sorunu ve teması olarak tekrar analiz edilmiştir. Böylelikle sorunun daha iyi anlaşılması ve buna uygun çözüm önerilerinin geliştirilmesi mümkün olmaktadır. Balık kılçı̆̆ı şemaları istenirse destekli olarak, sorunun diğer tarafında çözüm önerisi verilecek şekilde sunulabilir.

Özellikle doğuda yapılan kaliteye yönelik kalkınma hamlelerinde, önemli katkı sağlayan nitelik artırma tekniklerinin, sektör ve üniversitenin yaptı̆̆ 1 ortak araştırma çalışmalarına olumlu katkı sağlayabileceği düşünülmektedir. Burada ele alınan tekniklerin hepsi halen fiilen özel sektör tarafından zaten kullanılmaktadır. Fakat akademisyenlerin geliştirdikleri bu tekniklerin özel sektör tarafından rağbet görüp, turizm akademik çevresinde yeterince değerlendirilmediği görülmektedir. Turizm ve rekreasyon alanında yapılan lisansüstü çalışmalarda, bu tür tekniklerin belirlenen ana araştırma yöntemini destekleyecek şekilde kullanılması, araştırmaların daha sağlıklı ve anlaşılır sonuçlar üretmesine yardımcı olabilecektir.

\section{KAYNAKÇA}

Aktinson, P. ve Hammersley, M. (1998). Ethnography And Participant Observation İçinde; N. K. Denzin ve Y. S. Lincoln (Editörler), Strategies of Qualitative Inquiry (ss. 248-261). Thousand Oaks: Sage.

Bhattacharjee, S., Reichard, G., McCoy, A., Pearce, A. ve Beliveau, Y. (2014). Identification Of Elements To Control And Regulate Residential Energy Consumption, Advances in Building Energy Research, 8 (2): 174-195.

Ilie, G. ve Ciocoiu, C.N. (2010). Application Of Fishbone Diagram To Determine The Risk Of An Event With Multiple Causes, Management Research And Practice, 2 (1): 1-20.

Juran, J. M. (1954). Universals in Management Planning and Controlling, The Management Review, 43 (11): 748-761.

Juran, J. M. (1975). The Non-Pareto Principle; Mea Culpa, Quality Progress, 8 (5): 8-9.
Knights, P. F. (2001). Rethinking Pareto Analysis: Maintenance Applications Of Logarithmic Scatterplots, Journal of Quality in Maintenance Engineering, 7 (4): 252-263.

Liliana, L. (2016). A New Model Of Ishikawa Diagram For Quality Assessment, IOP Conference Series: Materials Science and Engineering, 161 (1): 1-6, IOP Publishing.

Meneses-Falcón, C. (2020). "Living In The Brothel": Participant Observation In Hidden Contexts, The Social Science Journal, 1 (15): 1-15.

Nothnagle, M., Sicilia, J. M., Forman, S., Fish, J., Ellert, W., Gebhard, R., Kelly, B.F., Pfenninger, J. L., Tuggy, M. ve Rodney, M. (2008). Required Procedural Training In Family Medicine Residency: A Consensus Statement, Family Medicine-Kansas City, 40 (4): 248-252.

Pareto, V. (1897). The New Theories of Economics, Journal of Political Economy, 5 (4): 485-502.

Power, R. (2001). Reflections On Participant Observation In Drugs Research, Addiction Research \& Theory, 9 (4): 325337.

Radson, D. ve Boyd, H.A. (1997). The Pareto Principle and Rate Analysis, Quality Engineering, 10 (2): 223-229.

Varzakas, T. (2016). HACCP and ISO 22000: Risk Assessment in Conjunction with Other Food Safety Tools Such as FMEA, Ishikawa Diagrams and Pareto, Encyclopedia of Food and Health, 295-302.

Walsh, K. (2020). Participant Observation. İçinde; A. Kobayashi (Editör). International Encyclopedia of Human $\mathrm{Ge}$ ography (ss. 39-42), Reference Work, 2. Bask1. Elsevier.

Özkan TÜTÜNCÜ, Prof. Dr., Dokuz Eylül Üniversitesi, Necat Hepkon Spor Bilimleri Fakültesi, Rekreasyon Bölümü, 35330, Seferihisar, Izmir.

E-posta: ozkan.tutuncu@deu.edu.tr

ORCID: 0000-0002-2482-0893

Betül KORKMAZ ORHAN, Araş. Gör., Selçuk Üniversitesi, Turizm Fakültesi, Turizm İşletmeciliği Bölümü, Alaeddin Keykubat Kampüsü, 42075, Selçuklu, Konya.

E-posta: korkmaz-betul@hotmail.com

ORCID: 0000-0001-9907-2298

Seda ÖZDEMIR AKGÜL, Araş. Gör. Dr., Selçuk Üniversitesi, Turizm Fakültesi, Turizm İşletmeciliği Bölümü, Alaeddin Keykubat Kampüsü, 42075, Selçuklu, Konya.

E-posta: sedaozdemir8@gmail.com

ORCID: 0000-0003-4482-4119 